\title{
Impact of the volume and the profile of volatile fatty acids in the rumen fermentation on cow productivity and milk composition
}

\section{Katarzyna Mikołajczyk , Ewa Pecka-Kietb ${ }^{7 *}$, Andrzej Zachwieja}

\author{
'Wroclaw University of Environmental and Life Sciences, Department of Biostructure \\ and Animal Physiology, Norwida 31, 50-375 Wroclaw, Poland \\ ${ }^{2}$ Wroclaw University of Environmental and Life Sciences, ${ }^{2}$ Department of Cattle Breeding \\ and Milk Production, Chełmońskiego 38c, 51-630 Wroclaw, Poland \\ *Corresponding author: ewa.pecka@upwr.edu.pl
}

\section{Abstract}

The aim of the research was to establish relations between the selected rumen fermentation products and the milk composition in dairy cows. The experiment was conducted on 10 Polish Holstein-Friesian cows of black and white variety. The animals were kept in the free stall housing system and fed with the total mixed ration (TMR). The herd's milk production was assessed using the A4 method and the milk analyses were obtained from the milk recordings. The rumen digesta were sampled two hours after the morning delivery of TMR using a stomach pump. The sampled digesta were diluted with buffer, homogenized and the obtained suspension was analysed using gas chromatograph with the FID detector to determine the total concentration of volatile fatty acids (VFA) and the percentage of individual VFAs. Milk composition was obtained from the RW-1 reports, and the Pearson correlation coefficient was calculated for the obtained parameters. It was determined that propionate and the relation of propionate to butyrate in the rumen digesta increased the protein content and its fractions in milk. The volatile fatty acids utilization coefficient in the rumen digesta a positive correlation to protein contents and a negative correlation to the level of caseins in milk were shown. Processes taking place in the cow rumen significantly influence the composition and quality of milk. The knowledge of volatile fatty acids content and the of individual VFAs allows for the management of the rumen fermentation in order to obtain better technological parameters of milk.

\section{Key words: milk composition, rumen digesta, volatile fatty acids, cows}

\section{Introduction}

Milk and its products play a vital role in human nutrition. They contain valuable proteins, fats, vitamins and minerals which are necessary for the proper functioning of human and animal organisms. Milk has antihypertensive, antibacterial and immunomodulatory properties (Chilliard et al., 2001; Januś and
Borkowska, 2011). It contains over four hundred fatty acids, about one hundred proteins and peptides, and non-protein nitrogen compounds such as urea (Spek et al., 2013). The milk produced by Polish Holstein-Friesian cattle of black and white variety has a high content of casein fractions and fat, which increases the production of high-quality milk products, including rennet cheese (Neja et al., 2013). 
Milk composition depends on genetic and environmental factors (Hurtaud et al., 1993; Pecka et al., 2013; Boro et al., 2016). One of the non-genetic factors determining milk composition is nutrition of animals. Deficits of energy, fiber and other components of feedstuff causes unfavorable changes in the microbial fermentation processes in the cow rumen (Knegsel et al., 2005; Benchaar et al., 2007; Halachmi et al., 2009). One of the indicators of fermentation processes in the rumen is, among others, the production of volatile fatty acids and the proportions of acetate and butyrate. Volatile fatty acids absorbed in the digestive tract of cows affect the milk quality (Cardozo et al., 2005).

The aim of the research was to determine the relation of selected rumen fermentation products and cow milk composition.

\section{Materials and methods}

Animals

The experiment was conducted in the herd of Polish Holstein-Friesian cows of Black and white variety. The animals were kept in the free stall housing system and fed TMR composed of: corn silage $492 \mathrm{~g} \mathrm{~kg}^{-1}$, alfalfa hylage $87.9 \mathrm{~g} \mathrm{~kg}^{-1}$, hay 26.4 $\mathrm{g} \mathrm{kg}^{-1}$, alfalfa green fodder $290 \mathrm{~g} \mathrm{~kg}^{-1}$, rapeseed meal $35.1 \mathrm{~g} \mathrm{~kg}^{-1}$, barley $26.4 \mathrm{~g} \mathrm{~kg}^{-1}$, lupine $17.6 \mathrm{~g}$ $\mathrm{kg}^{-1}$, triticale $17.6 \mathrm{~g} \mathrm{~kg}^{-1}$ and vitamin mixture $7.0 \mathrm{~g}$ $\mathrm{kg}^{-1}$. The milk production of the herd was recorded using the A4 method. The animals were selected following the analogy principle: age and milk production in the previous lactation were taken into account. Cows selected for the experiment were in the second or third lactation with average milk yield of $8500 \mathrm{~L}$ in the previous lactation. The feed ration was composed according to INRA norms (IZ-INRA 2009). The animals could drink water ad libitum, were kept in good zoohygienic conditions, were healthy and had no symptoms of diseases.

\section{In vitro fermentation}

The rumen digesta were sampled two hours after the morning delivery of the TMR using the intraruminal pump. They were then transported to the lab in the temperature of $39^{\circ} \mathrm{C}$ in anaerobic conditions. In the lab, the inoculums were diluted with the buffer (McDougall, 1948) in 1:3 ration and then homogenized. The obtained solution was centrifuged and formic acid was added $(0.1 \mathrm{~mL}$ per $2 \mathrm{~mL}$ of the solution) in order to stop the fermentation processes.

In order to determine the total volatile fatty acids concentration (VFA) and the proportion of individual acids: acetate, propionate, isobutyrate, butyrate, isovalerate, valerate and caproate, liquid samples were analysed using the $7890 \mathrm{~A}$ gas chromatograph (Agilent Technologies) equipped with a flame ionization detector (FID) and Agilent $J \& W$ column DB-WAX with helium as the carrier gas (flow $25 \mathrm{~mL} \mathrm{~min}^{-1}$ ). Identification and concentration of volatile fatty acids in the analysed samples was performed by comparing retention time and the peak area with the Sulpeco standard using ChemStation software.

\section{Cow performance and milk composition}

Test day records were used to obtain information on milk composition and cow performance (RW-1).

\section{Calculations and statistical analysis}

On the basis of the level and profile of volatile fatty acids analysis, utilization coefficient (NGR) expressed as the ratio of nonglucogenic to glucogenic VFA was calculated using the Ørskov equation (1975) modified by Abrahamse et al. (2008): NGR $=(A+2 B+B C) /(P+B C)$. Also the coefficient of fermentation efficiency ( $\mathrm{FE}$ ) was calculated using the equation modified by Baran and Žitřan (2002): $F E=(0.622 A+1.092 P+1.56 B) 100 /(A+P+2 B)$. Where $A, P$ and $B$ stand for the share of acetate, propionate and butyrate in the total concentration of VFA ( $\mathrm{mol} \%)$, and $\mathrm{BC}$ is the share of valerate and short-chain fatty acids. The ratios of acetate to propionate $(A: P)$ and propionate to butyrate $(P: B)$ in the cow rumen digesta were also calculated.

Statistical analysis of data was performed using the Statistica 13.1 software (StatSoft Polska, Kraków, Polska); the Pearson correlation coefficient was calculated. Differences between means were considered statistically significant if $\mathrm{P}<0.05$ and $\mathrm{P}<0.01$. 


\section{Results and discussion}

Protein content in cow milk depends on the amount of protein and energy delivered to the rumen microbiota with the feedstuff (Benchaar et al., 2007). Transformation of carbohydrates in the rumen is responsible for the level of fat, which is a valuable component of milk. Fat influences the taste of milk and determines the structure and texture of cheese (Urbach, 1990; Wiking et al., 2006).

In this research, average contents of these components in milk were similar (Table 1). $80 \%$ of milk proteins are casein micelles with whey protein constituting the remaining $20 \%$ (Artegoitia et al., 2014); in this research the casein content was $2.68 \pm 0.2 \%$, which constitutes $78.4 \%$ of total protein. The usual content of dry matter, protein, fat and lactose in the milk of healthy cows is $13 \%, 3.46 \%, 3.3-6.4 \%$, 4,8\% respectively (Malacarne 2002; Król et al., 2011; Januś and Borkowska, 2011; Gantner et al., 2015; Ahmad et al., 2008), which corresponded well to the average contents of these components in milk analysed within the present study (Table 1). $80 \%$ of milk proteins are casein micelles with whey protein constituting the remaining $20 \%$ (Artegoitia et al., 2014); in this research the casein content was $2.68 \pm 0.2 \%$, which constitutes $78.4 \%$ of total protein.

TABLE 1. Basic statistical parameters of daily milk traits

\begin{tabular}{l|l|l|l|l|l} 
Trait / statistical parameter & Mean & Minimum & Maximum & Median & SD \\
\hline Milk performance [kg] & 24.35 & 21.40 & 27.10 & 24.70 & 1.91 \\
\hline Fat [\%] & 4.02 & 2.37 & 5.40 & 4.03 & 0.78 \\
\hline Protein [\%] & 3.42 & 3.03 & 3.68 & 3.43 & 0.21 \\
\hline Casein [\%] & 2.68 & 2.35 & 2.87 & 2.71 & 0.16 \\
\hline Lactose [\%] & 4.93 & 4.71 & 5.16 & 4.95 & 0.13 \\
\hline Dry matter [\%] & 13.04 & 11.42 & 14.63 & 13.14 & 0.90 \\
\hline Urea [mg L-1] & 222.60 & 134.00 & 285.00 & 225.00 & 49.64 \\
\hline Fat : protein & 1.18 & 0.70 & 1.61 & 1.16 & 0.23
\end{tabular}

TABLE 2. Basic statistical parameters of rumen fermentation profile in cows

\begin{tabular}{l|l|l|l|l|l} 
& Mean & Minimum & Maximum & Median & SD \\
\hline Total VFAs & 97.98 & 69.73 & 137.64 & 95.82 & 21.24 \\
\hline Acetate $^{2}$ & 69.46 & 63.08 & 72.25 & 70.16 & 2.60 \\
\hline Propionate $^{2}$ & 17.48 & 14.13 & 22.37 & 17.43 & 2.58 \\
\hline Isobutyrate $^{2}$ & 0.74 & 0.60 & 0.82 & 0.76 & 0.07 \\
\hline Butyrate $^{2}$ & 9.47 & 5.85 & 13.07 & 9.85 & 1.96 \\
\hline Isovalerate $^{2}$ & 1.28 & 1.01 & 1.66 & 1.25 & 0.19 \\
\hline Valerate $^{2}$ & 1.21 & 0.83 & 2.21 & 1.09 & 0.41 \\
\hline Caproate $^{2}$ & 0.36 & 0.00 & 0.62 & 0.39 & 0.18 \\
\hline A:P & 4.06 & 2.82 & 5.11 & 4.00 & 0.69 \\
\hline P:B & 1.96 & 1.09 & 3.43 & 1.78 & 0.67 \\
\hline NGR & 4.92 & 3.48 & 6.41 & 4.82 & 0.93 \\
\hline FE & 72.79 & 71.40 & 75.18 & 72.63 & 1.04
\end{tabular}

${ }^{1} \mathrm{mmol} / \mathrm{L}$ of not diluted ruminal fluid; ${ }^{2}$ individual, $\mathrm{mol} 100 \mathrm{~mol}^{-1} ; 3 \%$

Normal fat to protein ratio and urea level in this research suggest a well-balanced feed ratio. In healthy animals fed an adequate diet, the fat to protein ratio oscillates between 1.1 and 1.3, and the urea level ranges from 200 to $300 \mathrm{mg} \mathrm{L}^{-1}$. Changes in the urea level and the fat share may suggest a lack of protein-energy balance in the feed (Buttchereit et al., 2010). Normal fat to pro- 
tein ratio and urea level in this research suggest a well-balanced feed ratio.

In this research, the VFA production was consistent with the literature data (Table 2). In the fermentation process, rumen microbiota produces volatile fatty acids whose total concentration in the rumen is about $95 \mathrm{mmol} \mathrm{L}^{-1}$ (DeFrain et al., 2004). They provide $70-80 \%$ of metabolic energy (Bergman, 1990, Pecka-Kiełb et al., 2018). In this research, the VFA production was consistent with the literature data (Table 2).

The results obtained in the experiment correspond to the literature data and imply that the animals' nutrition was adequate and the resulting rumen fermentation processes were normal (Table 2). The main VFA produced in the rumen is acetate (Beauchemin and McGinn, 2006). Berg- man (1990) estimated its proportion as 60-80 mol $\%$ of the total volume of VFA. Propionate comes second with its normal concentration of $17 \mathrm{~mol}$ $\%$ (Sutton et al., 2003), but Maxin (2010) estimates its production at $21.6 \mathrm{~mol} \%$. The production of butyrate is similar, its concentration in the ruminal fluid is about $15 \mathrm{~mol} \%$ (DeFrain et al., 2004). The proportions of isobutyrate and isovalerate produced in the fermentation process suggest the activity of proteolytic bacteria in the rumen (Vlaeminck et al., 2004). The total amount of these iso-acids in the rumen digest is 1-2.5 mol\% (Miśta et al., 2014). The results obtained in the experiment correspond to the literature data and imply that the animals' nutrition was adequate and the resulting rumen fermentation processes were normal (Table 2).

TABLE 3. Correlation coefficients between daily milk traits and the total volume and profile of VFA in the rumen fermentation in cows

\begin{tabular}{l|l|l|l|l|l|l|l|l} 
& $\begin{array}{l}\text { Milk } \\
\text { performance } \\
\mathrm{kg}]\end{array}$ & $\begin{array}{l}\text { Fat } \\
{[\%]}\end{array}$ & $\begin{array}{l}\text { Protein } \\
{[\%]}\end{array}$ & $\begin{array}{l}\text { Casein } \\
{[\%]}\end{array}$ & $\begin{array}{l}\text { Lactose } \\
{[\%]}\end{array}$ & $\begin{array}{l}\text { Dry } \\
\text { matter } \\
{\left[\mathrm{mg} \mathrm{L}^{-1}\right]}\end{array}$ & $\begin{array}{l}\text { Urea } \\
{[\%]}\end{array}$ & $\begin{array}{l}\text { Fat : } \\
\text { protein }\end{array}$ \\
\hline Total VFAs & 0.147 & -0.294 & 0.042 & 0.078 & 0.115 & -0.199 & -0.589 & -0.311 \\
\hline Acetate $^{2}$ & -0.385 & 0.118 & -0.432 & -0.445 & -0.010 & -0.016 & 0.536 & 0.255 \\
\hline Propionate $^{2}$ & -0.036 & 0.008 & $0.758^{*}$ & $0.727^{*}$ & -0.285 & 0.146 & -0.179 & -0.245 \\
\hline Isobutyrate $^{2}$ & -0.189 & -0.359 & 0.163 & 0.092 & -0.407 & -0.344 & 0.528 & -0.438 \\
\hline Butyrate $^{2}$ & 0.567 & -0.166 & -0.530 & -0.481 & 0.335 & -0.208 & -0.351 & 0.020 \\
\hline Isovalerate $^{2}$ & -0.362 & 0.080 & 0.292 & 0.317 & 0.167 & 0.161 & 0.206 & -0.017 \\
\hline Valerate $^{2}$ & 0.066 & -0.070 & 0.437 & 0.461 & 0.173 & 0.085 & $-0.765^{* *}$ & -0.209 \\
\hline Caproate $^{2}$ & 0.194 & 0.219 & -0.217 & -0.169 & 0.154 & 0.197 & -0.022 & 0.295 \\
\hline A:P & -0.056 & 0.027 & $0.743^{*}$ & $-0.712^{*}$ & 0.250 & -0.118 & 0.186 & 0.275 \\
\hline P:B & -0.418 & 0.194 & $0.676^{*}$ & $0.636^{*}$ & -0.406 & 0.267 & 0.310 & -0.038 \\
\hline NGR & 0.097 & -0.011 & $0.777^{* *}$ & $-0.741^{*}$ & 0.270 & -0.153 & 0.129 & 0.251 \\
\hline FE 3 & 0.169 & -0.051 & $0.652^{*}$ & $0.638^{*}$ & -0.179 & 0.091 & -0.350 & -0.265
\end{tabular}

${ }^{1} \mathrm{mmol} / \mathrm{L}$ of not diluted ruminal fluid; ${ }^{2}$ individual, $\mathrm{mol} 100 \mathrm{~mol}^{-1} ;{ }^{3} \%$; ${ }^{*}(\mathrm{P}<0.05),{ }^{* *}(\mathrm{P}<0.01)$ - $\mathrm{P}$-value - probability value for statistics

Increased production of volatile fatty acids in the rumen has positive influence on milk production in dairy cows (Hurtaud et al., 1993). Seymour et al. (2005) proved a positive correlation ( $r=0.22)$ between the total contraction of VFA in the rumen and milk production, which confirms the results of this research.The results obtained in this research indicate a positive correlation between acetate and the fat content in milk. Acetate takes part in the synthesis of fat in milk and colostrum (Tagang et al. 2010). The level of propionate and its ratio to bu- tyrate in the rumen suggest a strong correlation to/ with milk proteins and caseins $(P<0.05)$. Propionate is a high energy volatile fatty acid determining the level of substances synthesized by the udder cells - including caseins (Raggio et al., 2006). The level of propionate and its ratio to butyrate in the rumen suggest a strong correlation to/with milk proteins and caseins $(P<0.05)$. Seymour et al. (2005) presented a positive correlation between the milk production and the levels of butyrate $(r=0.69)$ and propionate $(r=0.49)$ in the ruminal fluid. Moreover, 
in his study there was a weak positive correlation $(r=0.04)$ between the concentration of propionate and the contents of milk proteins.

In this research, a strong negative correlation was established between the total VFA concentration and the urea content in milk. Moreover, statistically higher level of urea in milk was accompanied by a decreased production of valerate in the ruminal fluid $(\mathrm{P}<0.01)$. In cows, adequate feeding determines VFA production in the rumen, and - as a result - influences the level of urea in milk (Wanapat et al., 2009). In this research, a strong negative correlation was established between the total VFA concentration and the urea content in milk. Moreover, statistically higher level of urea in milk was accompanied by a decreased production of valerate in the ruminal fluid $(P<0.01)$.

NGR is defined as the ratio of non-glucogenic to glucogenic volatile fatty acids is called the utilization coefficient (Morvay et al., 2011). In this research, high NGR value indicates large energy losses (Ørskov, 1975). A strong negative correlation between NGR and the casein content in milk $(P<0.05)$ may have resulted from the loss of metabolic energy and might lead to a decrease in an- imal productivity, including the milk components synthesized in the mammary glands. No studies analysing how the VFA utilization coefficient and performance traits relate have been found in the literature on the subject.

\section{Conclusion}

The results obtained in the present study indicate that the concentration of volatile fatty acids (VFA) and the proportions of their fractions influence the performance of cows as well as the quality and composition of milk. Due to an important relation between the concentration of propionate and total milk protein as well as milk casein, it is possible to conclude that propionate is the main rumen fermentation product determining the quality of cow milk.

The relation between the concentration of VFA, the proportions of their fractions in the ruminal fluid and milk composition presented in this study suggest that continuing the research into the rumen fermentation profile modifications in order to obtain better technological properties of milk is desirable.

\section{Utjecaj volumena i profila hlapivih masnih kiselina u fermentu buraga na produktivnost krava i sastav mlijeka}

\section{Sažetak}

Cilj ovog rada bio je utvrditi odnose između odabranih produkata fermentacije u buragu i sastava mlijeka muznih krava. Istraživanje je provedeno na 10 krava pasmine holstein-friesian. Životinje su držane u slobodnom stajskom uzgoju i hranjene TMR-om. Produktivnost stada određena je pomoću A4 metode, a podaci o sastavu mlijeka dobiveni su iz centralnog sustava praćenja. Ferment iz buraga izuzet je pomoću želučane pumpe 2 sata nakon jutarnje hranidbe smjesom TMR. Izuzeti uzorci razrijeđeni su puferom i homogenizirani, a dobivena suspenzija je analizirana pomoću plinskog kromatografa opremljenog s FID detektorom kako bi se odredila koncentracija ukupnih, kao i udjeli pojedinačnih hlapivih masnih kiselina (VFA). Sastav mlijeka preuzet je iz zapisa sustava praćenja RW-1, a koeficijent korelacije prema Pearsonu je izračunat iz dobivenih parametara. Utvrđeno je da se odnos propionat/butirat u fermentu buraga povećava s povećanjem udjela proteina i proteinskih frakcija u mlijeku. Koeficijent iskoristivosti hlapivih masnih kiselina u fermentu buraga pokazao je pozitivnu korelaciju s udjelom proteina i negativnu korelaciju s koncentracijom kazeina u mlijeku. Procesi koji se odvijaju u kravljem buragu značajno utječu na sastav i kvalitetu mlijeka. Spoznaje o ukupnom sadržaju kao i sadržaju pojedinih hlapivih masnih kiselina omogućuju podešavanje upravljanja fermentacijom u buragu u svrhu dobivanja boljih tehnoloških svojstava mlijeka.

\section{Ključne riječi: sastav mlijeka, ferment buraga, hlapive masne kiseline, krave}


1. Abrahamse, P.A., Vlaeminck, B., Tamminga, S., Dijkstra, J. (2008): The effect of silage and concentrate type on intake behavior, rumen function, and milk production in dairy cows in early and late lactation. Journal of Dairy Sciences 91 (12), 4778-4792. https://doi.org/10.3168/jds.2008-1350

2. Ahmad, S., Gaucher, I., Rousseau, F., Beaucher, E., Piot, M., Grongnet, J. F., Gaucheron, F. (2008): Effects of acidification on physico-chemical characteristics of buffalo milk: A comparison with cow's milk. Food Chemistry 106, 11-17. https://doi.org/10.1016/j.foodchem.2007.04.021

3. Artegoitia, A., Meikle, A., Olazabal, L., Damian, J.P., Adrien, M.L., Mattiauda, D.A., Bermudez, J., Torre, A., Carriquiry, M. (2014): Milk casein and fatty acid fractions in early lactation are affected by nutritional regulation of body condition score at the beginning of the transition period in primiparous and multiparous cows under grazing conditions. Journal of Animal Physiology and Animal Nutrition 97 (5), 919-932. https://doi.org/10.1111/j.1439-0396.2012.01338.x

4. Baran, M., Žitňan, R. (2002): Effect of monensin sodium on fermentation efficiency in sheep rumen (short communication). Archives Animal Breeding 45 (2), 181-185. https://doi.org/10.5194/aab-45-181-2002

5. Beauchemin, K.A., McGinn, S.M. (2006): Methane emissions from beef cattle: Effects of fumaric acid, essential oil, and canola oil. Journal of Animal Science 84 (6), 1489-1496. https://doi.org/10.2527/2006.8461489x

6. Benchaar. C., Petit, H.V., Berthiaume, R., Ouellet, D.R., Chiquette, J., Chouinard, P.Y. (2007): Effects of essential oils on digestion, ruminal fermentation, rumen microbial populations, milk production, and milk composition in dairy cows fed alfalfa silage or corn. Journal of Dairy Sciences 90 (2), 886-897. https://doi.org/10.3168/jds.s0022-0302(07)71572-2

7. Bergman, E.N. (1990): Energy contributions of volatile fatty acids from the gastrointestinal tract in various species. Physiological Reviews 70 (2), 567-90. https://doi.org/10.1152/physrev.1990.70.2.567

8. Boro, P., Naha, B.C., Prakash, C., Madkar, A., Kumar, N., Kumari, A., Channa, G.P. (2016): Genetic and non-genetic factors affercting milk composition in dairy cows. International Journal of Advanced Research 6 (2), 170-174.

9. Buttchereit, N., Stamer, E., Junge, W., Thaller, G. (2010): Evaluation of five lactation curve models fitted for fat:protein ratio of milk and daily energy balance. Journal of Dairy Sciences 93 (4), 1702-1712. https://doi.org/10.3168/jds.2009-2198

10. Cardozo, P.W., Calsamiglia, S., Ferret, A., C. Kamel, C. (2005): Screening for the effects of natural plant extracts at different $\mathrm{pH}$ on in vitro rumen microbial fermentation of a high-concentrate diet for beef cattle. Journal of Animal Science 83 (11), 2572-2579. https://doi.org/10.2527/2005.83112572x

11. Chilliard, Y., Ferlay, A., Doreau, M. (2001): Effect of different types of forages, animal fat or marine oils in cow's diet on milk fat secretion and composition, especially conjugated linoleic acid (CLA) and polyunsaturated fatty acids. Livestock Production Science 70 (1-2), 31-48. https://doi.org/10.1016/s0301-6226(01)00196-8
12. DeFrain, J.M., Hippen, A.R., Kalscheur, K.F., Schingoethe, D.J. (2004): Feeding lactose increases ruminal butyrate and plasma $\beta$-hydroxybutyrate in lactating dairy cows. Journal of Dairy Sciences 87 (8), 2486-94. https://doi.org/10.3168/jds.s0022-0302(04)73373-1

13. Gantner, V., Mijić, P., Baban, M., Škrtić, Z., Turalija, A. (2015): The overall and fat composition of milk of various species. Mljekarstvo 65 (4), 223-231. https://doi.org/10.15567/mljekarstvo.2015.0401

14. Halachmi, I., Shoshani, E., Solomon, R., Maltz, E., Miron, J. (2009): Feeding soyhulls to high-yielding dairy cows increased milk production, but not milking frequency, in an automatic milking system. Journal of Dairy Sciences 92 (5), 2317-25. https://doi.org/10.3168/jds.2007-0958

15. Hurtaud, C., Rulquin, H., Verite, R. (1993): Effect of infused volatile fatty acids and caseinate on milk composition and coagulation in dairy cows. Journal of Dairy Sciences 76 (10), 3011-3020. https://doi.org/10.3168/jds.s0022-0302(93)77640-7

16. IZ-INRA (2009): Standards for Cattle Nutrition. (In: Standards for Ruminants Nutrition. National Research Institute of Animal Production, Kraków): 21-81 (In Polish).

17. Januś, E., Borkowska D. (2011): Effect of selected factors on milk energy value of cow's milk from phf bw and Montbeliarde breeds. Żywność. Nauka. Technologia. Jakość 78 (5), 141-149. https://doi.org/10.15193/zntj/2011/78/141-149

18. Król, J., Brodziak, A., Litwińczuk, A. (2011): Podstawowy skład chemiczny i zawartość wybranych białek serwtkowych w mleku krów różnych raz i w serwatce podpuszczkowej; Żywność. Nauka. Technologia. Jakość 4 (77), 74-83. https://doi.org/10.15193/zntj/2011/77/074-083

19. Malacarne, M., Martuzzi, F., Summer, A., Mariani, P. (2002): Protein and fat composition of mare's milk: some nutritional remarks with reference to human and cow's milk. International Dairy Journal 12 (11), 869-877. https://doi.org/10.1016/s0958-6946(02)00120-6

20. Maxin, G., Glasser, F., Rulquin, H. (2010): Additive effects of trans-10, cis-12 conjugated linoleic acid and propionic acid on milk fat content and composition in dairy cows. Journal of Dairy Science 77 (3), 295-301. https://doi.org/10.1017/s0022029910000233

21. McDougall, E.I. (1948): Studies on Ruminant Saliva. 1. The composition and output of sheep's saliva. Biochemical Journal 43 (1), 99-109. https://doi.org/10.1042/bj0430099

22. Miśta, D., Pecka, E., Zachwieja, A., Zawadzki, W., Bodarski, R., Paczyńska, K., Tumanowicz, J., Kupczyński, R., Adamski, M. (2014): In vitro ruminal fluid fermentation as influenced by corn-derived dried distillers' grains with solubles. Folia Biologica (Krakow) 62 (4), 345-351. https://doi.org/10.3409/fb62_4.345

23. Morvay, Y., Bannink, A., France, J., Kebreab, E., Dijkstra, J. (2011): Evaluation of models to predict the stoichiometry of volatile fatty acid profiles in rumen fluid of lactating Holstein cows. Journal of Dairy Science 94 (6), 3063-3080. https://doi.org/10.3168/jds.2010-3995 
24. Neja, W., Jankowska, M., Sawa, A., Bogucki, M. (2013): Analysis of milk and reproductive performance of the active population of cows in Poland. Journal of Central European Agriculture 14 (1), 91-101. https://doi.org/10.5513/jcea01/14.1.1161

25. Pecka, E., Zachwieja, A., Tumanowicz, J. (2013): Technological parameters of milk depending on the cow housing system, nutrition system, age and number of somatic cells. Przemyst Chemiczny 92 (6), 1087-1091.

26. Pecka-Kiełb, E., Zachwieja, A., Wojtas, E., Zawadzki, W. (2018): Influence of nutrition on the quality of colostrum and milk of ruminants. Mljekarstvo 68 (3), 169-181. https://doi.org/10.15567/mljekarstvo.2018.0302

27. Ørskov, E.R. (1975): Manipulation of rumen fermentation for maximum food utilization. World Review of Nutrition and Dietetics 22, 153-182.

28. Raggio, G., Lobley, G.E., Lemosquet, S., Rulquin, H., Lapierre. H. (2006): Effect of casein and propionate supply on whole body protein metabolism in lactating dairy cows. Canadian Journal of Animal Science 86 (1), 81-89. https://doi.org/10.3168/jds.s0022-0302(06)72481-x

29. Seymour, W.M., Campbell, D.R., Johnson, Z.B. (2005): Relationships between rumen volatile fatty acid concentrations and milk production in dairy cows: a literature study. Animal Feed Science and Technology 119 (1-2), 155-169. https://doi.org/10.1016/j.anifeedsci.2004.10.001

30. Spek, J.W., Dijkstra, J., Duinkerken, G., van Bannink, A. (2013): A review of factors influencing milk urea concentration and its relationship with urinary urea excretion in lactating dairy cattle. Journal of Agricultural Science 151 (3), 407-423. https://doi.org/10.1017/s0021859612000561

31. Sutton, J.D., Dhanoa, M.S., Morant, S.V., France, J., Napper, D.J., Schuller, E. (2003): Rates of production of acetate, propionate, and butyrate in the rumen of lactating dairy cows given normal and low-roughage diets. Journal of Dairy Science 86 (11), 3620-3633. https://doi.org/10.3168/jds.s0022-0302(03)73968-x
32. Tagang, A., Patricia, I.K., Abdullah, A. (2010): Volatile fatty acids production in ruminants and the role of monocarboxylate transporters: A review. African Journal of Biotechnology 9 (38), 6229-6232.

33. Van Knegsel, A.T, van den Brand, H., Dijkstra, J., Tamminga, S., Kemp, B. (2005): Effect of dietary energy source on energy balance, production, metabolic disorders and reproduction in lactating dairy cattle. Reproduction Nutrition Development 45 (6), 665-688. https://doi.org/10.1051/rnd:2005059

34. Urbach, G. (1990): Effect of Feed on Flavor in Dairy Foods. Journal of Dairy Science 73 (12), 3639-3650. https://doi.org/10.3168/jds.s0022-0302(90)79067-4

35. Vlaeminck, B., Fievez, V., van Laa,r H., Demeyer, D. (2004): Rumen odd and branched chain fatty acids in relation to in vitro rumen volatile fatty acid productions and dietary characteristics of incubated substrates. Journal of Animal Physiology and Animal Nutrition 88 (11-12), 401-11. https://doi.org/10.1111/j.1439-0396.2004.00497.x

36. Wanapat, M., Polyorach, S., Boonnop, K., Mapato, C., Cherdthong, A. (2009): Effects of treating rice straw with urea or urea and calcium hydroxide upon intake, digestibility, rumen fermentation and milk yield of dairy cows. Livestock Science 125 (2), 238-243. https://doi.org/10.1016/j.livsci.2009.05.001

37. Wiking, L., Nielsen, J.H., Båvius, A.K., Edvardsson, A., Svennersten-Sjaunja, K. (2006): Impact of milking frequencies on the level of free fatty acids in milk, fat globule size, and fatty acid composition. Journal of Dairy Science 89 (3), 1004-9. https://doi.org/10.3168/jds.s0022-0302(06)72166-x 